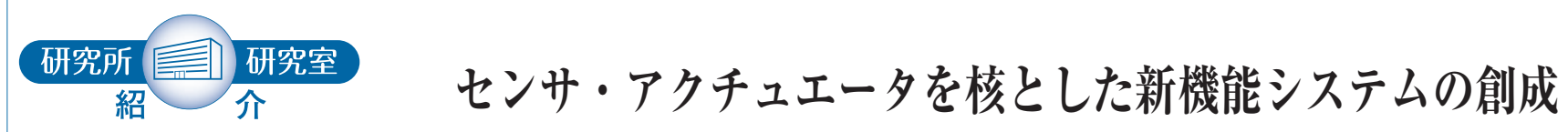

岡山大学大学院自然科学研究科 産業創成工学専攻 システム構成学教育研究分野

System Integration Laboratry Graduate School of Natural Science and Technology, Okayama University =700-8530 岡山県岡山市北区津島中 3-1-1 准教授 神田岳文

\section{TEL : 086-251-8159}

URL : http://www.act.sys.okayama-u.ac.jp

\section{1. 研究室の概要}

本研究室は, 岡山大学津島キャンパス内, 自然科学系総 合研究棟に居室・実験室を構えています。東京・新大阪方 面から山陽新幹線で岡山駅に到着する直前, 右手方向にそ の建物屋上の「岡山大学」の文字を見ることができます。

平成 13 (2001) 年の鈴森康一教授（現・東京工業大学 教授) の岡山大学着任とともに研究室として事実上の教育 研究活動を開始し, 平成 29 (2017) 年度が 17 年目となり ます。当初から, 各種アクチュエー夕に関する技術をもと に，各種メカトロニクス技術に関する研究を行ってきまし た. 現在は教員として神田岳文, 脇元修一の 2 名の准教授 が教育・研究に携わっています。大学院博士後期課程とし ては産業創成工学専攻, 同博士前期 (修士) 課程としては 機械システム工学専攻, 学部としては工学部機械システム 系学科システム工学コースの教育を担当しています.

平成 29 （2017）年 1 月現在, 研究室には上記教員 2 名 のほか, 技術補佐員 1 名, 非常勤研究員 1 名, 大学院博士 後期課程学生 1 名, 大学院博士前期 (修士) 課程学生 21 名, 学部学生 11 名が所属しています. 当然ながら, 研究 の多くは所属学生の教育と関連してして行っており, 原理 の考案, 設計・シミュレーション, 加工・製作, 制御を含 むシステム構築, 测定, 評価分析, さらに学会発表, 論文 発表まで一貫して行うようにしています。各種プロジェク トへの参加, 展示会出展, 学生による国際学会での発表も 積極的に行っています。研究室発足以来の卒業・修了生も 多数となり，製造業をはじめとする企業，あるいは大学・ 研究機関等で活躍しています（図1).

\section{2. 研究の内容}

従来, 流体 (空圧, 水圧, 油圧) アクチュエータ, 機能 性材料（圧電, 形状記憶合金など）を利用したアクチュエ

\section{FAX : 086-251-8159}

E-mail : kanda@sys.okayama-u.ac.jp

ー夕, 電磁・静電アクチュエータなどに関する研究を基盤 として, メカトロニクスシステムへの応用を進めてきまし た。現在も, アクチュエータをはじめとしてセンサを含む 新しい機能要素（デバイス）の創出により, これまでにな い新しい機能システムを実現し, 先端科学, 医療・福祉, 生産技術などの分野へ展開することを目標として研究を行 っています。以下, 研究課題の一部を紹介します.

\title{
2.1 特殊環境用マイクロアクチュエータ
}

主として圧電体の振動を駆動源とするアクチュエータ を, 低温・高温, 強磁場などの特殊環境で使用することを 目的とした研究を行っています.

極低温環境は, 熱ノイズが少ないなどの特徵から, 先端 的な科学計測分野において重要な環境となっています。図 2 は, 極低温環境である液体へリウム温度付近 $(4.5 \mathrm{~K}$ 程 度）において，回転駆動を実現した超音波モータとその実 験環境を示しています。また, ある種の測定器のサンプル 操作を目的として, 強磁場 (7 T 以上) 環境, さらに強磁 場下の極低温環境での駆動可能なモー夕の実現を目的とし た研究を行っています.

\section{2 マイクロ流体システム用デバイス}

岡山県下の大学・研究機関を中心として運営されてい る, 岡山マイクロリアクターネットの活動に研究室として 参画しています。これに関連して, マイクロリアクターな どの化学工学分野で用いることのできる流体システム用デ バイスに関する研究を行っています.

微小な単分散液滴は薬品, 食品, 電子材料や化粧品製造 等のさまざまな分野で利用されています。図 3 は, 高周 波振動を利用してナノメートル領域の液滴を含むエマルシ ヨン生成を行うマイクロ流路デバイスを示しています。水 への溶解度が低い薬剤を水中に微小な液滴として分散させ る「エマルション化」を行うために, 圧電振動子の超音波

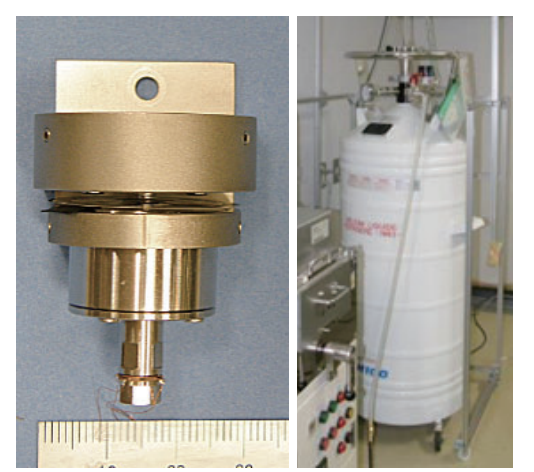

図1研究室のメンバー 


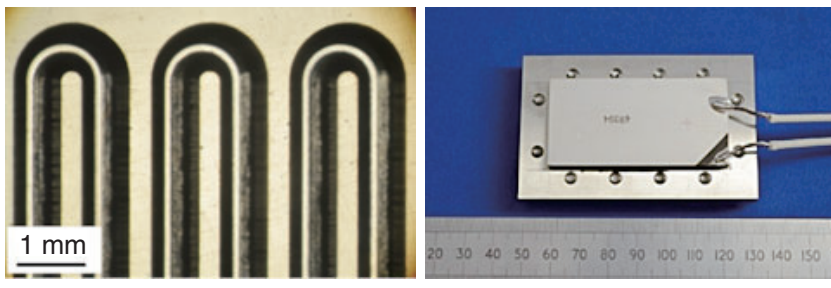

図 3 ナノエマルション生成を目的としたマイクロ流路デバイス

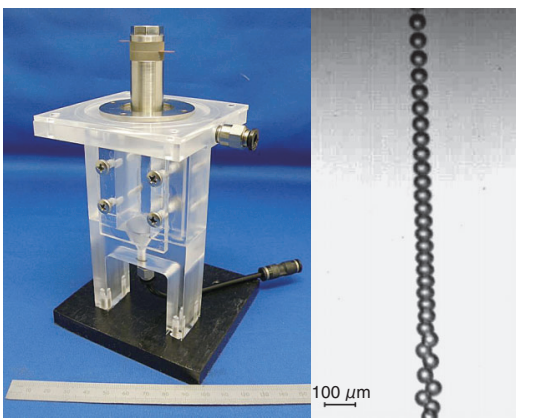

図 4 液滴生成用振動子と生成された液滴の様子

振動を用いた小型かつフロー型のナノエマルション生成デ バイスの開発を行っています.

また，超音波振動子を用いて数十マイクロメートルオー ダーの液滴生成に関する研究も行っています．図４は, 微小孔板を取り付けたランジュバン型ねじり振動子を用い て液滴の生成を行っている様子を示しています。空気中や 連続相液体中に微小な単分散液滴の生成を効率良く行うこ とができます。

このほかにもマイクロミキサやバルブ, 微小液滴の分級 を行うデバイスなどマイクロ化学の分野で利用されるさま ざまなデバイスに関する研究を行っています。さらに，小 型のバルブに関する研究は, 流体アクチュエータの駆動シ ステムの小型化を目的とした研究へも発展しています.

\section{3 ソフトアクチュエータとその応用}

ゴムなどの柔らかい材料からなるソフトメカニズムは, 柔軟性・形状適応性・滑らかな動作を特徵とし, 医療・福 祉・バイオ分野への応用が期待されています。柔軟な構造 をもつさまざまな空圧アクチュエー夕を試作し、ソフトメ カニズムへの応用を進めています。

図 5 では，空圧アクチュエータの一種である McKibben 型人工筋の細径化を進め, さらに複数の人工筋を組み合わ せて，柔軟なマニピュレータとして駆動した例を示してい ます，細径人工筋を組み合わせることによって，タコの腕 を模した構造を実現しています。それぞれの人工筋が独立 あるいは複合して収縮動作をすることによって，収縮・伸 長・湾曲・ねじれ・剛性変化の柔軟で複雑な動作が可能と なります。このほかにも細径 McKibben 型人工筋を用い ることによりさまざまな形状の多自由度アクチュエータを 実現しています。また，ソフトメカニズムの表面に微細構
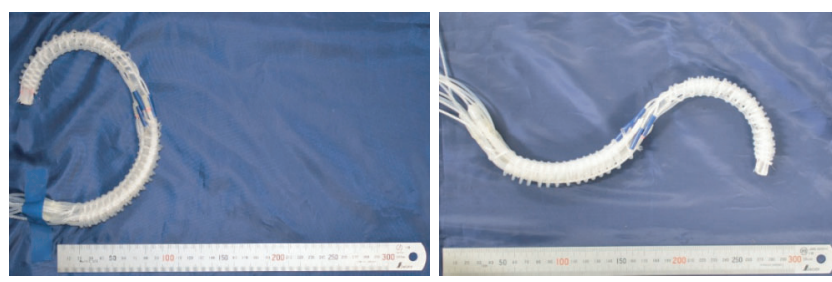

図 5 細径 McKibben 型人工筋により構成した柔軟マニピュレータ の駆動の様子
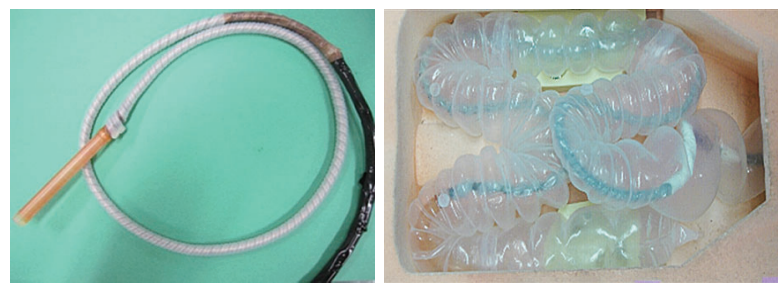

図 6 大腸内視鏡挿入支援アクチュエー夕と実験の様子

造を形成することによって表面機能の付加を試み，操作対 象や使用環境の拡張を目指しています, 吸着, 発色, 撥 水, 低摩擦などの機能を有するソフトメカニズム表面の開 発に取り組んでいます。

\section{4 医療用流体駆動アクチュエータ}

前述のと㧍り, ゴムなどの材料を使用し流体圧力の印加 によって駆動する流体駆動ソフトアクチュエータは高い柔 軟性を有し，また，低コストで製作可能です。このような 特徵を生かし，医療用途を目的とした流体駆動ソフトアク チュエー夕の開発を実施しています。一例として, 図 6 に大腸内視鏡検査に抢いて，内視鏡に巻き付けることによ って挿入を支援する空圧駆動のチューブ状アクチュエータ を示しています。 アクチュエータ表面のチューブ状構造で 進行波を生成し, 容易で安全に内視鏡が挿入されるよう支 援します。低剛性の内視鏡にアクチュエータを搭載するこ とが, 腸壁への負荷を軽減した挿入に寄与することを大腸 モデルへの挿入実験で確認しています。

このほか, 空圧アクチュエータがX 線を透過しやすい 特性をもつことを利用した, 胃 X 線検査において圧迫撮 影を支援する空圧駆動の圧迫機構など，医療検査を支援す る各種アクチュエータに関する研究を行っています。

\section{3.おわりに}

研究活動においては企業・研究機関との連携も重要視し て抢り，多くの共同研究を実施してきました。また，学内 の他分野を含めた研究者とは「岡山大学アクチュエー夕研 究センター」の活動を共同で行っており, 異分野融合研究 の推進にも努めています。

研究室の活動内容に興味がある方は, 研究室のウェブサ イト（http://www.act.sys.okayama-u.ac.jp）もご覧くた さい，末筆ながら，研究室設立以来ご支援をいただいてお ります学内外多くの皆様に感謝の意を表します。 